\title{
US embargoes nuclear fuel exports to Europe
}

THE United States is refusing to issue any further licences for the export of nuclear fuels to the member countries of the European Economic Community until these countries agree to renegotiate the current agreement between EURATOM and the US covering the terms of such exports.

Although the embargo covers all nuclear fuels, as well as power station equipment, it is likely to have a particular impact on nuclear research and development in France, Germany, Denmark and Holland which rely almost entirely on the US for supplies of highly enriched uranium.

The American move follows the signing by President Carter on 10 March of the Nuclear Non-proliferation Act, which lists a number of conditions under which the US is prepared to export nuclear fuels. This is aimed at reducing the danger of the proliferation of nuclear weapons. Under the terms of the act, all the US's exisiting export agreements were to be honoured provided the other party involved indicated within 30 days their readiness to renegotiate existing agreements in line with the new act.

So far, however, EURATOM has not given any indication that it is prepared to renegotiate its existing 20-year treaty. This has been largely because of complaints-particularly from the French-that the US has no right to break the agreement unilaterally, and the feeling that no action should be taken before the conclusions are known of the International Nuclear Fuel Cycle Evaluation (INFCE) which was established last year on President Carter's own initiative, and which is not expected to report until the end of 1979.

In an attempt to minimise any embarrassment caused by the embargo, the US Nuclear Regulatory Commission (NRC) passed all pending licence applications whose paperwork had been completed on 7 April, the last working day before the embargo came into effect. But a number of applications for nuclear fuel were not completed in time. Among them was one from EURATOM's high flux reactor at the Petten Research Centre in Holland for $22.6 \mathrm{~kg}$ of highly enriched uranium, submitted to the US last June.

Although the Petten application had been approved by both the Executive Branch and the State Department at the beginning of March, it has been held up within the internal NRC review process, along with two other applications for nuclear fuel from the Netherlands. NRC officials say that the applications lacked sufficient formal confirmation that the Dutch plants satisfied the criteria on 'physical security' which are contained in the new non-proliferation act.

However other sources in Washington say the NRC is concerned about possible threats to plutonium caused by the recent activities of the Moluccan terrorists in Holland. It has also been implied that any application for nuclear fuel from Italy would have little chance of success in the present political climate.

With the passing of the nonproliferation act, the role of the NRC, which is responsible for seeing that any application for nuclear fuel meets the safeguard and security criteria expressed in the act, has taken on a particular significance in international relations.

In the more overtly political arena, President Carter is now treading a cautious path. He has, for example, maintained a diplomatic silence on the conclusions of the Parker report on reprocessing at Windscale, despite the fact that the report rejects much of the logic of the President's stance.

Even a letter from a number of key congressmen on the non-proliferation issue--including Senator John Glenn and Representatives Clement Zablocki and Jonathan B. Bingham-claiming the proposal to expand reprocessing at Windscale and La Hague in France to be "dangerously premature and obviously inconsistent with the INFCE initiative", was unable to stir the President into making a strong statement. The State Department, too, having been criticised for appearing to be attempting to interfere with the internal politics of other states (for cxample, in its submission to the UK government on Windscale) is being careful not to tread on too many toes.
In this situation, focus has come to rest on the NRC. And the sensitivity of its role was illustrated by last week's decision by the four commissioners, as the result of a tied 2-2 vote, to reject an application from India for fuel to be used in the Tarapur nuclear power reactor. The two commissioners who voted against the application, Peter Bradford and Victor Gilinsky, said they felt the export licence did not meet three of the six requirements of the non-proliferation act, covering safeguards, the possible use of plutonium to make explosives, and US control over reprocessing. The commissioners voted unanimously that the licence application should be forwarded to President Carter, who can approve it if he finds it in the national security interest of the US to do so--even though such a decision can be subsequently overturned by congress.

Officials in Washington are hoping to to avoid a similar confrontation with the member countries of EURATOM. But much depends on the outcome of discussions taking place in Brussels this week on an EEC response to the US demands for renegotiation of the EURATOM agreement.

Dr Guido Brunner, EEC Commissioner for Energy, met French representatives last Monday in an attempt to calm the initial hostility that the US moves have generated, and it is expected that a letter will soon be sent to Washington in which the EURATOM countries, while not directly agreeing to renegotiate as such, will at least indicate that they are prepared to 'talk' about renegotiation.

They hope this will be enough to get the embargo on the export of nuclear fuels lifted, at least temporarily. But the subsequent negotiations promise to be long and acrimonious.

David Dickson

\section{California rejects major nuclear power plant}

A legislative committee in California last week rejected legislation that would have permitted the construction of a $\$ 3$ billion nuclear power plant because of the problems of the safe disposal of nuclear waste.

Supporters of the Sundesert power plant, presenting a case that even environmentalists accepted was stronger than other applications being made elsewhere, pointed out that it would have been built far from urban concentrations, and was the only pending nuclear power plant in the US that had received both federal and state clearance for site safety including earthquake safety.
However, the state assembly's Resources, Land Use and Energy Committee said it had not been convinced that the supporters had a completely feasible scheme for the safe disposal of nuclear waste, even though the state senate had approved the exemption of Sundesert from the state's waste-disposal laws.

The decision represents a victory for Governor Edmund (Jerry) Brown and his attempts to lead the state away from a nuclear future. Alternatives that Governor Brown is particularly enthusiastic to support include the construction of a coal-fired plant and the repowering of an existing plant. $\square$ 